\title{
The Teacher Technology Integration Experience: Practice and Reflection in the Classroom
}

\author{
Dana Ruggiero \\ Bath Spa University, Bath, \\ United Kingdom
}

d.ruggiero@bathspa.ac.uk

\author{
Christopher J. Mong \\ University of Arkansas at Little \\ Rock, Little Rock, AR, USA
}

cjmong@ualr.edu

\begin{abstract}
Material published as part of this publication, either on-line or in print, is copyrighted by the Informing Science Institute. Permission to make digital or paper copy of part or all of these works for personal or classroom use is granted without fee provided that the copies are not made or distributed for profit or commercial advantage AND that copies 1) bear this notice in full and 2) give the full citation on the first page. It is permissible to abstract these works so long as credit is given. To copy in all other cases or to republish or to post on a server or to redistribute to lists requires specific permission and payment of a fee. Contact Publisher@InformingScience.org to request redistribution permission.
\end{abstract}

Previous studies indicated that the technology integration practices of teachers in the classroom often did not match their teaching styles. Researchers concluded that this was due, at least partially, to external barriers that prevented teachers from using technology in ways that matched their practiced teaching style. Many of these barriers, such as professional support and access to hardware and software, have been largely diminished over the last twenty years due to an influx of money and strategies for enhancing technology in primary and secondary schools in the United States. This mixed-methods research study was designed to examine the question, "What technology do teachers use and how do they use that technology to facilitate student learning?"

K-12 classroom teachers were purposefully selected based on their full-time employment in a public, private, or religious school in a Midwestern state in the United States, supported by the endorsement of a school official. There were 1048 teachers from over 100 school corporations who completed an online survey consisting of six questions about classroom technology tools and professional development involving technology. Survey results suggest that technology integration is pervasive in the classroom with the most often used technology tool identified as PowerPoint. Moreover, teachers identified that training about technology is most effective when it is contextually based in their own classroom. Follow-up interviews were conducted with ten percent $(n=111)$ of the teachers in order to examine the relationship between teachers' daily classroom use of technology and their pedagogical practices. Results suggest a close relationship; for example, teachers with student-centric technology activities were supported by student-centric pedagogical practices in other areas. Moreover, teachers with strongly student-centered practices tended to exhibit a more pronounced need to create learning opportunities with technology as a base for enhancing $21 \mathrm{st}$ century skills in students. Teachers indicated that external barriers do exist that impact technology integration, such as a lack of in-service training, a lack of available technology, and restricted curriculum, but that overcoming internal barriers, including personal in-

vestment in technology, attitude towards technology, and peer support, were a bigger indicator of success. Recommendations are made for restructuring professional development on strategies for contextualizing technology integration in the classroom.

Keywords: technology use, technology integration, in-service teacher, professional development. 


\section{Introduction}

Technology integration has been an ongoing process among educators and education researchers for the past three decades (Ertmer, Ottenbreit-Leftwich, Sadik, Sendurur, \& Sendurur, 2012). Over 35,000 articles and abstracts have been published about technology integration in education reviewing current practices, recommending effective strategies, and restructuring policy with a large percentage of the articles discussing the nature of technology in the classroom. Ertmer (2005) reported that there are two types of barriers to implementing technology in the classroom: external barriers referring to resources, training, and support, and internal barriers, such as teacher confidence, beliefs about student learning, and value of technology in the classroom. Since the article appeared, there have been other studies examining obstacles to achieving technology integration (Arrowood, Davis, Semingson, \& Maldonado, 2010; Stobaugh \& Tassell, 2011), underlying perceptions of teachers (Ertmer, 2005; Pierson, 2001; Zhao, Pugh, Sheldon, \& Byers, 2002). However, the technology divide still exists. This gap exists within teaching itself, preparation for teaching with technology, and implementation of technology at different levels.

It has been well established that technology is not a cure all for improving classroom instruction (Ertmer, 2005) and within the classroom an instructor must be able to use technology and connect it to the content (Pierson, 2001; Stobaugh \& Tassell, 2011). A deficiency in either area can lead to failure, yet content and pedagogical knowledge are often seen as precursors to successful technology integration - a good teacher should be able to use technology in a pedagogically sound way. Research over the last ten years suggests that in order for technology integration to be fully accepted in the classroom, the teacher needs to be a key stakeholder in the adoption process and to help create the active learning process that will allow technology to take root and grow as an indispensable tool of education (e.g., Arrowood et al., 2010; Ertmer et al., 2012; Vannatta \& Banister, 2009). Both theoretical and practical research have focused on teacher beliefs (Dexter \& Anderson, 2002; Hadley \& Sheingold, 1993) in order to pinpoint how technology is integrated effectively into the classroom.

Prior research on teacher beliefs and technology integration (Becker, 1994; Dwyer, 1991; Fisher, Dwyer, \& Yocum, 1996) reported that teachers who were more student centered still used technology in fairly routine ways, such as typing practice and games after classwork was completed. By 2005, access to technology such as classroom computers and the Internet increased (National Center for Educational Statistics, 2006), bringing the focus of technology integration on pedagogy rather than technology. Research in the last eight years (for example, Andrew, 2007; Gray, Thomas, \& Lewis, 2010; Hermans, Tondeur, van Braak, \& Valcke, 2008; Koehler \& Mishra, 2009) has indicated that increasing the amount of technology in the classroom was not sufficient to change teachers' technology practices without a shift in the teachers' pedagogical practices. In general, teachers faced barriers, such as a restricted curriculum and lack of training in using technology, stifling the use of technology in practices aligned with their pedagogical practices. Three factors have appeared repeatedly in the current literature: hardware and software, teacher training, and professional support.

\section{Hardware and Software}

Lack of hardware and software were historically seen as barriers to implementing technology effectively in the classroom in the United States. However, the percentage of state funded schools connected to the Internet rose from 35\% in 1994 to nearly 100\% in 2005 (Wells \& Lewis, 2006). Gray et al. (2010) reported that $97 \%$ of teachers from a 2009 NCES study had access to one or more computers in the classroom. In addition to hardware, the wide availability of web tools has made lack of software less of an issue to any teacher with Internet access. Given this, teachers no longer need to purchase expensive software or hardware to provide access to digital content. Teachers have already begun to adjust their classrooms to integrate these tools. Classroom use of 
Internet-based videos and podcasts has increased more than 50\% since 2008 (Project Tomorrow, 2011). Moreover, $96 \%$ of teachers reported using Internet-based communications tools to connect with parents and other teachers. Today, teachers can create, use, and share resources using their classroom computer without having to purchase any software.

\section{Teacher Training}

Teacher training in the United States is one of the most cited reasons for lack technology implementation in the classroom (Birch, 2008). While this still continues to be an impediment to effective technology integration, recent survey results suggest that it is improving. Based on the NEA (National Education Association [NEA], 2008) results, the majority of teachers in the United States reported feeling adequately trained to operate technology equipment (68\%) and to search on the Internet (71\%). This finding is supported by the Teachers Talk Tech survey (CDW-G, 2006 ) where $63 \%$ rated their skills as somewhat advanced to advanced.

\section{Professional Support}

Professional support needed for effective technology integration can include administrative, peer, and technological support in American schools. Project Tomorrow (2011) reported that only 30\% of school administrators viewed technology support as a top challenge. Ertmer et al., (2012), referencing Education Week, reported that $83 \%$ of responding schools employed a staff person in an educational technology role. Both of these studies indicated that schools in the United States were confident about their ability to support technology integration within their schools.

\section{Research Question}

The recent improvements in support of technology integration within the classroom provide the opportunity to examine the relationship between what technology teachers use and how they use it within their classrooms. In order to gain a deeper understanding and broader sense of the state of technology integration within primary, middle, and secondary classrooms, this research proposes to explore the daily experience of classroom teachers as they use technology to create learning opportunities for their students. This study is designed to examine one question:

What technology do teachers use and how do they use that technology to facilitate student learning?

The importance of this question lies in our understanding of what technology integration adds to a traditional education and how current programs are preparing teachers to teach with technology. Given the growth of technology in the field of education, it is more important now for researchers and practitioners to understand how current teachers are using it to create meaningful learning opportunities for students in compulsory education.

\section{Methodology}

\section{Participants}

In total, 1048 in-service teachers from across a Midwestern state in the United States completed the online survey. Approximately $77 \%$ of the participants were female and $51 \%$ of participants were over 40 years old. The mean number of years teaching was 14.6 years with a minimum of 2 months and maximum of 40 years of experience. Primary teachers (with students aged 5 to 10) accounted for $48 \%$ of the teachers with middle school (with students aged 11 to 13 years old) accounting for $23 \%$ and secondary school (with students aged 14 to 18 years old) accounting for $28 \%$. Within the in-service teacher participant set ten percent $(n=111)$ were randomly selected to participate in follow-up individual focus interviews. Of these participants, the demographics were 
similar to the larger population. The follow up interviews took place using two formats: in-person interviews and online interviews. The focus interviews were used to confirm themes that arose during the broader survey collection. The focus participants participated in either online or inperson semi-structured interviews. Participants were from a wide variety of primary, middle, and secondary schools that served a range of culturally, linguistically, and economically diverse student populations.

\section{Materials and Procedures}

A survey was developed to help answer the important question uncovered during a literature review on teacher perceptions of technology integration: What technology do teachers use and how do they use that technology to facilitate student learning? To explore this question, we collected both qualitative and quantitative data. This paper explores the experiences of individuals who are currently teaching in a primary, middle, or secondary setting and is a smaller part of a wider study on teacher pedagogical belief in relation to technology integration in the classroom.

This study used purposive sampling in order to identify and select those individuals employed as in-service teachers. Purposive sampling makes sense in this case since the research questions require participants with specific characteristics (Johnson \& Christensen, 2008). These participants were identified by snowball sampling where we emailed current principals to recommend qualified participants who fit the criteria (full-time teachers) of the study. In total, 1048 in-service teachers from across a Midwestern state in the United States participated. In order to accomplish this, a phenomenological approach was used, which Johnson and Christensen (2008) note is meant "to describe one or more individuals' experiences of a phenomenon" (p. 394). This required an in-depth interaction with the participants (Patton, 2002). An online survey tool was used to collect data. The participants were asked four demographic questions and two questions specific to their use of technology in the classroom. In addition they were asked to enter their contact information if they were willing to be interviewed. Follow up participants were asked four semi-structured questions. Survey and interview questions are shown in Table 1.

Table 1: Survey Questions

\section{Demographic Questions}

1. What is your gender?

2. What is your age range?

3. How many years have you been teaching full time?

4. Please identify your grade level and specialization (primary, middle, secondary)?

\section{Survey Questions}

1. What technology tools do you use in your classroom?

2. How do you learn about the tools you use in your classroom?

\section{Focus Interview Questions}

1. Define technology integration, what is your pedagogical approach to using technology in the classroom?

2. In a typical day, how do you utilize technology in your classroom? What does learning with technology look like?

3. Please talk about the technology you have access to in your classroom.

4. What are the positives/negatives of having technology in the classroom? 


\section{Data Collection}

Data collection was guided by our interest in examining the relationship between the pedagogical principles and technology practices of teachers in the classroom. The primary sources of data for this study were surveys, in-person interviews, and online interviews.

\section{Surveys}

A survey was created using an online survey program. This survey was administered once to each participant using an online system. The two survey questions were derived from the Teaching, Learning, and Computing (TLC) National Survey of Schools and Teachers conducted by Dr. Henry Jay Becker and Dr. Ronald E. Anderson in 1998 (Becker, 2000). The surveys assessed constructs such as the participants' teaching philosophy using technology, technology tool preferences, technology beliefs, use of technology in the classroom, and opportunities for technology growth. Likert scale, open-ended questions, and pick, group, and rank responses were included in the survey. Each participant was emailed a link to the survey and connected through an anonymous server that assigned a random 10-digit alphanumeric code to each survey response. All surveys were administered over the Internet, with an average duration of activity of approximately 19 minutes.

\section{In-person interviews}

The researchers conducted one 30-minute interview with sixteen of the in-service teacher participants over the course of five months. The individual interviewees were asked the four focus interview questions and were asked to provide examples from their classroom teaching. Most interviews were conducted at either a local restaurant or a local library. All interviews were conducted using a qualitative approach (Patton, 2002) and were audio recorded with the permission of the interviewee. To elicit spontaneous interaction the participants were encouraged to ask questions and pose answers in response to each of the four questions that we asked.

\section{Online interviews}

The researchers used online interviews to gather additional data from participants that could not, geographically or time wise, be interviewed in person. Ninety-five in-service teachers participated in online interviews. These interviews were conducted in the same way as in-person but were done using online meetings. The participants were emailed the link to the meeting and encouraged to spend as much time as desired explaining their answers to the interviewer.

\section{Data Analysis Procedure}

A mixed-methods research design was used to examine the similarities and differences among technology integration practices. Quantitative data (demographics and scale ratings of technology tools) were analyzed using simple descriptive statistics while interview and qualitative survey

data were analyzed using a constant comparison method to identify patterns among each teacher's practices. Finally, individual reports of how teachers use technology on a daily basis were analyzed thematically, which provided triangulation data to support any observed relationships among technology practices.

\section{Role of the researchers}

This study was designed and conducted by a team of two researchers, both interested in exploring connections between teacher pedagogical principles and technology integration practices. A secure online survey was created to track information about the participants during the selection process and to capture team member insights on interview data. Interviews were conducted by 
one researcher and transcribed by the other so that both team members were familiar with the data. The first round of data analysis was completed by the two team members then discussed among a group of three qualitative research doctoral students for coding. The coding team was comprised of four graduate students in an advanced qualitative measures class at an academic institution under the guidance of a doctoral-level instructor. One of the researchers had been a classroom teacher for six years prior to the study and one was the head TA in an educational technology class that all pre-service teachers take at the university; the researchers led the data analysis until consensus was reached regarding overall themes.

\section{Results}

\section{Descriptive Statistics and Patterns}

Descriptive statistics for survey question 1 (What technology tools do you use in your classroom?) were calculated via SPSS. The results are displayed in Figure 1 and illustrate the diversity of technology use across K-12 education in this population. This question was designed to analyze participants' perceptions of technology tool usefulness in the classroom and their time spent using specific tools. For the purpose of this study, a technology tool was defined as anything that used an additional input to produce learning materials, for example an overhead projector was considered to be a technology tool due to its ability to produce a larger image and its need for electricity. This definition was loosely constructed and in the final stages of compiling the technology tools list we included all the tools that had more than ten responses (at least $1 \%$ of the study population).

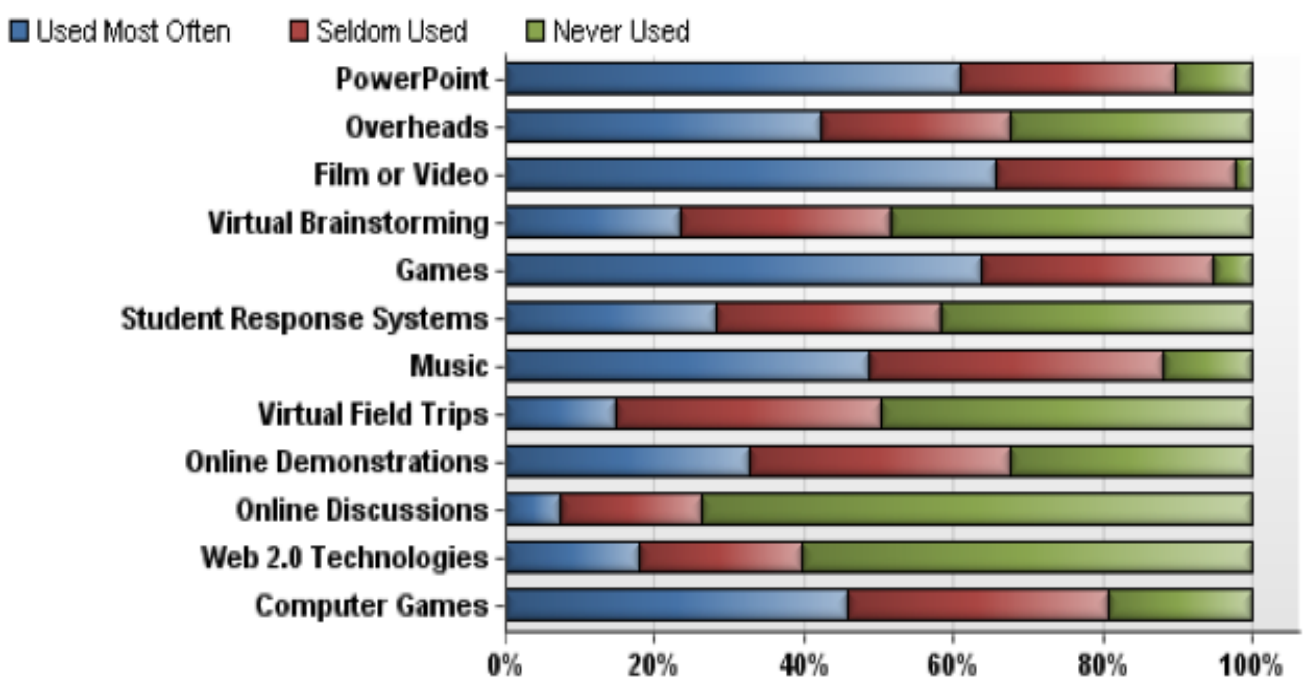

Figure 1: Technology Tools Used in the Classroom

Results of the descriptive analysis revealed that PowerPoint, film and video, and games are the technologies used most often across all age groups (Figure 1). More than $90 \%$ of teachers in the middle school and high school groups reported that film or video is the main technology tool used in their classroom. Web 2.0 technologies, with thousands of free websites for education, was ranked 10th by the teachers, only surpassing online discussions and virtual field trips. Computer games, music, and student response systems ranked in the middle with approximately $50 \%$ of teachers reporting to using these technologies in their classroom at least some of the time. Given the larger percentage of elementary teachers represented in the study (48\%), the technology tools associated with this population was strongly skewed towards 'used most often' using games, 
overheads, and music, while middle school and high school teachers were more likely to list these tools as seldom used. Despite the popularity of asynchronous social networking sites such as Facebook, Twitter, and LinkedIn, online discussions ranked highest for 'never used' in the classroom.

Survey question 2 was calculated in SPSS. A word cloud (Figure 2) was created to visualize the way that current teachers learn about technology tools with the most common words appearing larger. As seen in Figure 2, training is the most common way that teachers learn about technology tools. Moreover, training is broken down into three categories: online, workshops, and conferences. Online learning, accounting for approximately $27 \%$ of the teacher responses, takes place in school district sites or on contracted virtual learning environments. Workshops, including inservice days, accounted for $35 \%$ of the teacher responses and included daylong and multiple day learning sessions on specific tools such as Apple iPods and Smartboards. Conferences, accounting for $38 \%$ of teacher responses, include district and state conferences where teachers attend talks and demonstrations about the use of technology in the classroom. An example of this would be a master teacher using Garageband and Audacity, software for audio creation, to create podcasts for students and showing other teachers their process.

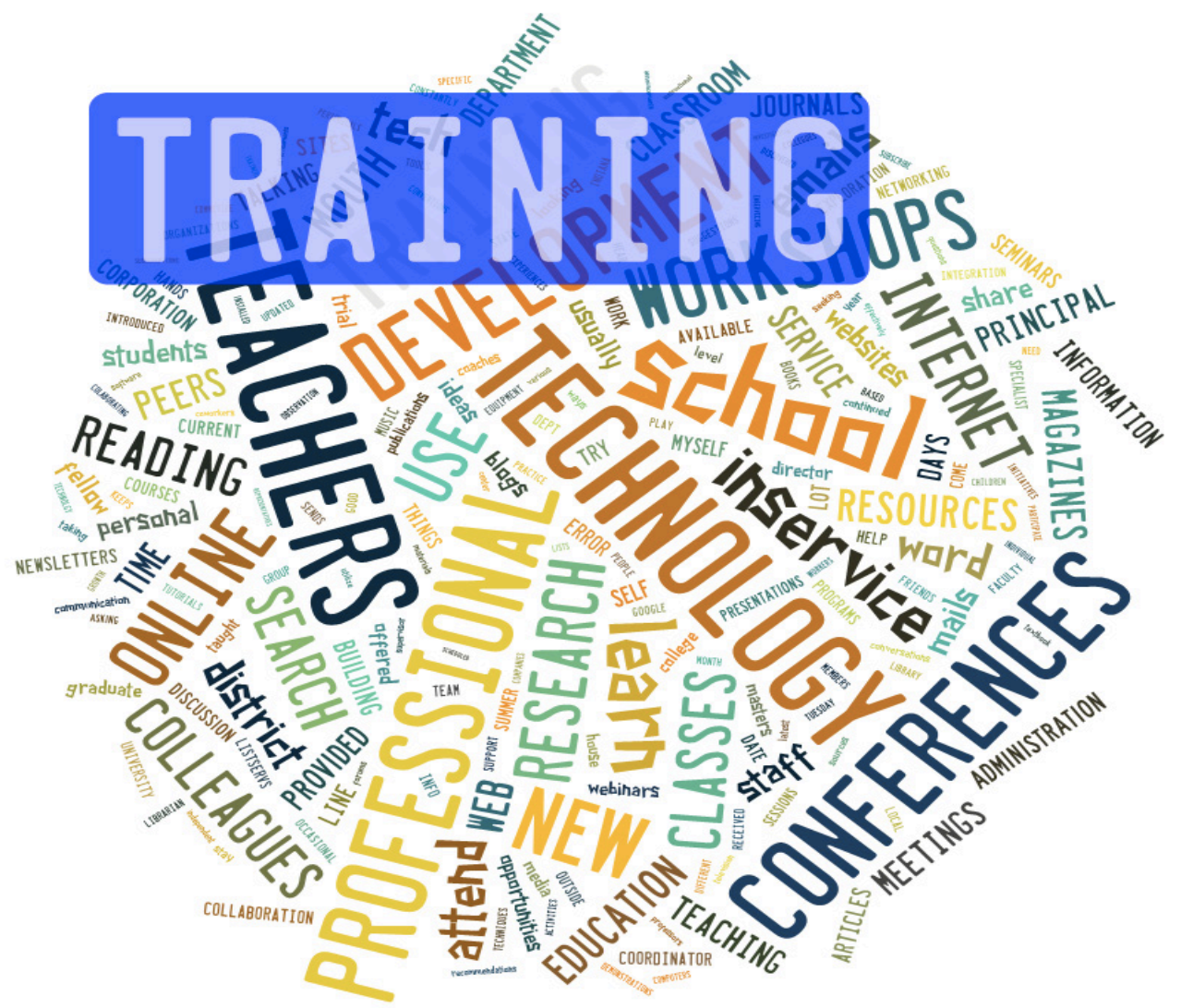

Figure 2: How Do You Learn About Technology?

In addition to training, teachers also learn about technology through professional development, reading, colleagues, research, and the Internet. Professional development, in the form of Masters courses and accredited classes for in-service teachers, offers teachers the chance to learn from practitioners and experts currently using the technology. Reading, research, and the Internet appeared as linked resources within the descriptive statistics. Approximately $60 \%$ of respondents reported using research, reading, and the Internet in conjunction with professional development or training. Finally, teachers learn about technology tools from each other. Elementary teachers were 
more likely ( $45 \%$ of teachers) to learn about technology tools such as the Smartboard from another teacher than high school or middle school teachers (approximately $21 \%$ ).

Teachers use and learn about technology tools in a variety of ways. The descriptive statistics provided patterns that inform about teacher technology use. One pattern which emerged was that elementary teachers are more likely to rate interactive technology tools as 'used most often' and high school teachers are more likely to rate presentation tools as 'used most often'. A second pattern is that the definition of a 'technology tool' is broadly defined among all teachers with those teachers having more experience (greater than 15 years) listing more technology tools than those with less experience. Finally, teachers learn about technology tools as contextually integrated systems rather than as standalone programs. Approximately $70 \%$ of responses to the question 'How do you learn about the tools you use in your classroom?' brought a response that included multiple information points rather than one point of knowledge.

Using these three patterns, four questions were developed for the focus group interviews. Ten percent of the survey participants were randomly sampled to participate, resulting in 111 responses. These responses were collected and analyzed for common themes based on research in the field of technology integration in the classroom.

\section{Thematic Analysis}

The richness of this data set allowed the research team to identify a variety of potential themes. In order to prioritize all of the themes and find nesting themes, the team decided those that related most closely to the research question should receive precedence. Themes that appeared most strongly supported, and appeared to have the most potential to shed new light on existing research, were selected to represent the study. Moreover, the research teams' interpretation of the data was justified based in that some themes that developed were in direct opposition to preconceptions and had been linked to the three patterns that emerged in the survey responses. Illustrative quotes were chosen based on their clarity and representation of the themes established. In order to keep the responses as anonymous as possible, the research team utilized pseudonyms and revised some quotes to create a smooth flow and ensure grammatical correctness. None of these changes altered the participants' meanings as ensured by member checks and dependability audits. Four themes regarding in-service teacher views on pedagogical principles and technology integration practices emerged from the data analysis:

1. Defining technology integration as a process

2. Design as a tool of technology

3. Use of technology in the primary, middle, and secondary classroom is seen as pervasive

4. Value of technology integration in the classroom is constantly changing

\section{Theme 1: Defining technology integration as a process.}

Several pieces came together to form this particular theme with the word process, or synonyms thereof, appearing most often in the responses. The integration of technology into daily classroom protocols is described below as a way of creating learning, a process, rather than a specific technology tool. Participants shared their overall view of technology integration as a process to create learning. Identifying multiple ways in which technology is integrated into the classroom on a daily basis, the participants paint a detailed picture in which the teacher creates schedules, schema, and frameworks to utilize technology in an efficient way.

In-service teachers conveyed the idea that technology and integration of that technology is a process. Through procedures and instructions, scaffolding and guiding, they build different components into their classroom. One 5th grade teacher stated, "Technology is science put to use," while another elementary teacher said, "Technology is the application of scientific knowledge to 
tools for everyday use." To use technology is not to ensure integration; technology integration is deeper than the mere appearance of tools in the curriculum. As one chemistry instructor stated, "Technology integration is using the technology as a natural part of the day in logical ways, as opposed to creating contrived assignments for the purpose of using technology or using the technology in ways that don't mesh well with the format."

Other teachers noted that the use of technology in the classroom makes learning easier and more engaging but must be tempered with using it wisely and efficiently to meet instructional goals. One middle school social studies teacher said, "It has to be reasonably seamless to work, and if it is thought of as an additional layer, it won't be very efficient." Participants expressed a wide range of responses to technology integration as a process of learning and instruction. Some were strong advocates of technology in the classroom using particular approaches while others note specific instances in which technology is best suited.

Another aspect of the process of integrating technology into the classroom is looking at how knowledge is presented. One first grade teacher stated, "Technology is a means . . . a mode ... the content is still most important, it is just delivering your voice and thought in a technological way." Still others talked about streamlining the process of learning by stating that technology integration is a way to teach several subjects at one time. A middle school science and math teacher added, "Integration is seamlessly incorporating the use of technology into the lesson plans so that the students' learning is enhanced and is a big help with cross-curricular teaching and differentiated learning." However, the influence of technology use is not always obvious in the quotations. That participants trying to use technology integration as a process for enhancing learning and instruction is seen through the researcher's discussions with them; but the way it is used and its influence is not always clear at the beginning. When asked, participants demonstrated how they used a technology integration process, which offered an illustration as to how they use technology in their classroom.

\section{Theme 2: Design-based learning as a tool of technology.}

Participants indicated that they use aspects of design to make sense of complex lessons. Rather than a schematic to follow in a step-by-step fashion, teachers used technology in an iterative cycle year to year and hone best practices from years of trial and error. Technology, used in this way, provides a tool to create learning scenarios that are rich in perspectives for interpreting and explaining content area lessons. Participants observed that the main contribution of design as a tool of technology was to provide an order or a way of creating order out of the multitude of choices they have, therein providing a schema for understanding how to best integrate technology within certain parameters.

Technology can affect the design of a class and restructure a lesson-based on student needs. One of the definitions that best describes how technology affects design came from a high school shop teacher who stated that integration is seamless when "technology can be used to invisibly enhance the educational experience." Other teachers also commented on the idea that technology does not need to be the center of the class in order to affect how a lesson is implemented. One third grade teacher noted that "technology integration should seamlessly provide additional illustrations and examples to the learning concepts," while a middle school math teacher divulged that "technology integration occurs when you can seamlessly weave technology into everyday lessons and activities. It should not be a 'special' thing that only gets used on days when you can get into the computer lab."

This brings up the question of how to design lessons using technology. To "use technology to help deliver instruction" as one high school science teacher opined there is a certain learning curve associated. Teachers surveyed for this study had taught between two months and forty 
years with a median of fourteen years in the classroom. Many of these teachers were going through pre-service teacher education classes before the government required a technology integration class in all teacher education programs. When asked how they learn about technology integration, many teachers replied that they have in-service trainings. A fourth grade teacher disclosed, "Usually I have one in-service training discussing a new device where all the users are crammed into a room for a day and then left to forge ahead on my own." Other teachers stated that they learn by using it. In the words of second grade teacher, "There is a "natural progression' of learning, workshops, and own investigation." While many teachers were self-taught, they adopted technology into their classrooms in a seamless way that incorporates instructional design.

Participants also reported that these design-based learning understandings of technology are helpful in determining future steps on how to use a certain tool in the classroom. In a sense, technology provided a framework for design (occasionally embedded in the context) for understanding certain technology tools and processes. When asked to describe a typical day using technology in their classrooms, teachers reported different design schemes. One fifth grade teacher, someone who has been teaching for over ten years and recently moved to a technology rich classroom, commented:

"The morning message is on the SmartBoard for all students to complete. All activities from our math program, Everyday Math, are shown on the SmartBoard. Students are always welcome to come and use the SmartBoard. During Science, videos can be easily viewed on the SmartBoard. We keep a science "Notebook". All notes for the notebook are saved in the SmarBoard system and can be viewed at any time. The Elmo is great for projecting steps before conducting a science experiments."

Another teacher, one that had been teaching first grade with technology for three years, stated,

"I teach first grade most of the day. We use a document camera to project our math book pages onto the interactive whiteboard. Usually I talk through a few examples of the math problem, using the stylus to write directly onto the whiteboard. Then I let students take turns solving the problems, again using the stylus. During snack time, we often play games on EducationCity.com, with students taking turns at the games, still using the stylus to play. Sometimes we use graphic organizers on diskprojected onto the whiteboard - when making webs, lists, T-charts, character maps, etc. in language arts. We often print the completed charts and display them in the hallway."

While the two previous examples are about the design of day to day use by the students with the teacher, the next two are more focused on how the teacher uses technology to take care of the back end details of teaching. One high school English teacher commented that, "I start by spending the first hour on my computer doing emails, grading submitted work, searching for new materials, etc." while another high school science teacher reported that,

"I use the computer to communicate with parents and staff members. I check the Internet for relevant science news to share with my class. I check the Internet for current global affairs news to share with my homeroom class. I enter grades on the computer. I use the overhead projector to show science transparencies. I have a lot of available technology to share with my class but cannot utilize it because I do not have a Smart Board, document camera, or an LCD projector connected to a computer. I teach technology, but I have very little to actually share with students."

The design of the class is greatly affected by the technology or lack of technology that is present to be integrated. To more effectively integrate technology into the design of the class one middle school social studies teacher commented that, 
"Students should be allowed to use their cell phones as calculators, to keep their personal schedules, timers, and research information. Teachers should have technology, such as iPads, to carry with them throughout the day to communicate with administrators, record activities and important information as they happen, and have a working clock. Teachers should be using cloud storage to share documents, such as tests, with each other. Having a shared drive is outdated. There are many other ideas that should be implemented."

As the researchers interviewed participants, it became clear that they utilized technology as a design process to a higher degree than they were being asked to currently. Participants named instances and resources that they had come across or been taught about and that would fit daily situations in their classroom but that their districts did not have available. Practically speaking, participants were able to recreate their classrooms with descriptions that show understanding of design as a technology tool and what can and cannot be accomplished with resources.

\section{Theme 3: Use of technology in the primary, middle, and secondary classroom is seen as pervasive.}

One thousand and forty-eight classroom teachers from across a Midwestern state took part in this study. When asked, "How do you use technology in the classroom?" the research team received a variety of responses ranging from the use of email and a daily attendance system to totally paperless classrooms using social media to share ideas. The common thread among all of the classroom teacher participants was that technology use was pervasive for whatever area it is being utilized. Teachers generally resisted the idea that technology integration should be used automatically in all situations. Using technology reflectively and constantly adjusting the breadth of its use was a suggestion shared by participants. The participants rejected relying on technology to, in one second grade teachers' words, "be the lesson" because specific instances in which a tool is taught is completely different then using subject area time to focus on something so one-dimensional. One high school math teacher asserted, "It would be like me teaching a year long class on how to use the calculator- it's a tool, not the actual lesson."

Teachers relied on technology in varying degrees for different areas. While some teachers were fully integrated, there were some who use technology only for specific purposes. Full integration of technology from start to finish was rare to find in this study, but there were some instances of teachers who have gone this route. One high school English teacher claimed,

"My classroom is approximately 99\% paper free. My students no longer need to bring paper or writing utensils to class. They use Moodle every day. They are either writing in a journal, doing an assignment, or using a resource of some sort. Consequently, they use the computers every day. My students also keep a blog, so have some type of assignment on it at least once a month. They are also allowed to blog on their own time, which many do. My English 12 class is book free, so the students do not have to bring anything to class."

While this is not the track that all teachers are on, the use of technology in the classroom was pervasive. One level of integration can lead to another and teachers find ways to use technology for more than one purpose at a time. One high school humanities teacher commented,

"Typically, we utilize the document camera, computer, projector and screen whether to display questions for discussion, student responses or to instruct (worksheet completion, grammar, etc.). This occurs on a daily basis. This is the 1st year with the iPod Touch Lab, and we try to have "iPod University Fridays". The iPods also help with literature study in terms of providing audio support and self-paced reading environment. The resource research has taken a lot of time, but we are better prepared 
for next year. The plan is to integrate daily vocabulary word, daily SAT question, and daily writing tip into our schedule."

A middle school math teacher opined,

"I work with several types of technology. I use the laptop and the LCD projector as a visual aid. I sometimes will use the smart board in teaching math as it lends itself to hands-on math. I use a mini economy in my classroom so my "Treasurer" will keep track of the students' banking in an Excel spreadsheet. I have used a classroom response system to give a quiz after a lesson. In the end it is all about the students and their understanding of the material."

Moreover, teachers were using technology as a means to increase student learning where they can. In order to accomplish this they are willing to integrate new models and methods.

From everyday use to specific instances, technology integration in the classroom from primary to secondary school was a growing concern. Even in schools without the "stuff" associated with technology, teachers were using it as a part of the daily routine. One fifth grade teacher commented, "I utilize technology from the moment I arrive at school (turning on my computer to check email) until the moment I leave. Students hear music, watch videos, view pictures, and use the Smartboard in a variety of lessons in my room." A fourth grade teacher added, "I use PowerPoint almost every day. I also like to show a lot of good video clips. Unfortunately, that is probably the most we use technology on a 'typical' day. It is hard to schedule computer lab time so those days aren't typical."

It was found that the teaching strategy used most in the classroom was problem solving, followed by group work. PowerPoint served as the technology tool used most often. Even with these findings, showing that classroom teachers used other teaching strategies over technology, the teachers surveyed for this study mention technology integration in some form over 16,000 times from using email, clickers, cell phones, Moodle, Blackboard, PowerPoint, Smartboards, keyboarding, digital video, and web surfing.

\section{Theme 4: Value of technology integration in the classroom is constantly changing.}

Teachers value technology in education. They did not talk about doing away with computers or creating spaces where technology is not welcome. Even participants who used little to no technology in their classroom on a daily basis voiced the importance of it for students in the changing world. For example, a sixth grade math teacher stated, "It doesn't matter that I don't use much in the way of technology in the classroom. They go out in the hallway and the phones come out, they go home and use Facebook to talk about the assignments, I have one student who has a math tutor based in India."

While there was not a 'typical' day in the classroom, the research team did find that the use of technology in the classrooms does not start and stop - it is fluid and integrated into the daily structure. Teachers spent less than $40 \%$ of their time standing in front of their class lecturing. The rest of the time was spent on interactive activities and student work. This demonstrated that there is a large amount of time when technology can be used to scaffold classroom instruction. Teachers listed technology as force of change but defined it in very different ways. One high school Spanish teacher commented, "Technology provides individualized and differentiated instruction; teachers become a facilitator of student learning and has time to provide mentorship." A middle school science teacher reported, "The students can reach more and better, worlds of education" when describing how technology is changing her students' outlook on science. Moreover, as technology integration becomes increasingly ubiquitous across education, it provides "the ability 
to address all types of learners. If the student is hands on learning, the Smartboard allows them to use the board to understand the concept. If the learner is a visual learner, the technology makes the lessons come alive," added a middle school math teacher.

With these comments, and many more about the change in technology integration, the researchers noted the shift from the physical nature of technology to its role in the mental processes that take place in the classroom. As one third grade teacher spoke, "Technology has gone from a tool that helps solve a problem to intangible devices that make learning easier," and many teachers see technology as a tool that straddles two dimensions: the physical and the mental. Technology and technology integration go hand in hand, and in the words of one second grade teacher, "Students are used to having technology at their fingertips and it is a tool that they use all the time at home. We have almost an endless number of resources that are only a click away and we don't have to leave the classroom. The technology can also be very highly motivating for many students." Technology, as seen by the teachers in this study, can be used for more than content knowledge; it can be used for affective processes such as motivation and engagement. As technology integration continues to change from the presentation mode, from PowerPoint, for example, to interactive such as virtual field trips and online discussions, more authentic learning experiences can continue to be developed, or, in the words of one high school health teacher, "bring reality and cool edge to the classroom."

\section{Discussion}

In this study, we examined the common threads among teacher views and reported uses of technology in the classroom. Participants reported that they value and use technology in their classrooms. Moreover, teachers seemed to appreciate that technology is available to them as a means of enhancing education and making it more authentic for the students. For example, teachers who felt that technology integration is a process described practices for integrating technology in which their own background played a part in the implementation. Teachers who believed that the process of technology integration was seamless described weaving technology tools into the curriculum using learning and teaching techniques to provide a scaffold. This finding is supported by what others have reported in the past (Hew \& Brush, 2007; Vannatta \& Banister, 2009). For example, Hew and Brush (2007) reported that teachers who were confident in their technology integration process were more likely to have developed procedures to facilitate technology seamlessly. The authors extend, as a possible explanation, that as technology has gotten more ubiquitous across the United States, teachers are integrating commonly used tools in a variety of ways. The areas proposed where teachers are becoming more comfortable with are design-based learning in technology integration, technology as a pervasive presence, and the value of change in technology.

The current push to prepare students for the 21st century (Bellanca \& Brandt, 2010; Ertmer et al., 2012; Silva, 2009) has put more technology in the classroom. The U.S. Department of Education (2010) in the 2010 National Education Technology Plan called for technology to be "an integral component of teaching methods" (p. XIV). National curricular organizations such as ISTE (International Society for Technology in Education, 2008) and NCATE (National Council for Accreditation of Teacher Education, 2011) called for a more integrated use of technology as well. Additionally, educational researchers reported on the need for teachers to incorporate 21 st century skills within the design of their curriculum (Britten, 2012; Trilling \& Fadel, 2009). Not surprisingly, teachers have responded to district and school strategies by incorporating more technology tools in their daily lessons. For example, of the nearly 300 school corporations surveyed in this study, with teacher respondents from over 200, participants reported that effective technology integration is an expectation of every teacher. As a result, teachers were encouraged and supported by their curriculum directors, principals, and teaching teams to implement curriculum that 
models technology integration as a key feature (Dede, 2010; Jenkins, Purushotma, Weigel, Clinton, \& Robison, 2009) to support student learning. Forty-five percent of primary teachers and $21 \%$ of middle and secondary teachers in the study referred specifically to these in-house and virtual supports as invaluable in their efforts to integrate technology. They claimed that access to a knowledgeable community of educators was a key factor to their growth in technology integration practices.

As noted by Arnone, Small, Chauncey \& McKenna (2011), technology was pervasive in the K-12 classroom. For example, teachers who had Smartboards in their classroom used it throughout the day rather than just for one subject (Giles \& Shaw, 2011). Technology has crept into every corner of the classroom, from math skills building in elementary schools (Hudson, Kadan, Lavin, \& Vasquez, 2010) to high school home economics (Lau \& Albion, 2010; Phua, Wong, \& Abu, 2012). The teachers in the study reported that technology integration within their classrooms was reflective and constantly adjusted based on the breadth of its use. However, it does not disappear - technology is underpinned by the curriculum and the curriculum is pervaded by the classroom technology. For example, $99 \%$ of respondents replied that they use technology on a daily basis in their classroom to support student learning. As reported by Gray et al. (2010), computer-student ratios are 1:2, an all-time low, although almost all U.S. teachers have access to the Internet in their classrooms. Additionally, the wide availability of free web tools (Schrum \& Levin, 2009) allowed teachers access to a wide variety of resources. In this study, teachers were quick to report on their technology integration practices as student directed rather than teacher directed. For example, a fifth grade teacher commented, "I tried it one time, just once [Jeopardy game on the interactive whiteboard] and now the kids demand it for all spelling and vocabulary practice tests." The pervasive use of technology in the classroom has shaped how teachers and students interact with content and this change is accelerating (Ertmer et al., 2012).

The technology of today shortly becomes the technology of yesterday in education. Technology and its uses are constantly changing to incorporate new ways of managing interactions on the digital plain (Dede, 2010). Thus, how teachers integrate technology into the classroom is a constantly moving target. New methods and tools are introduced, piloted, and take root or die quietly within education. For example, a seventh grade social studies teacher commented, "When I got the Smartboard last year it sat there for a couple of weeks before we used it. It took me months to get used to using it in class. My colleague down the hall [another seventh grade social studies teacher] uses hers to hang posters." In general teachers in this study were keen to integrate technology in ways that best support student learning and to the best of their ability. "Ten years ago I had one computer in my classroom, now I have a laptop cart, Smartboard, and peer to peer network. I learned to use [the tech tools] and now it's second nature." Furthermore, teachers in this study who kept abreast of the changing nature of technology spoke about being more able to provide effective learning opportunities across curriculums.

\section{Limitations and Suggestions for Future Research}

While 1048 teachers were surveyed for this study and 111 of those teachers were interviewed as a follow up, they were all from one state in the United States and the results are not generalizable. In order to verify these results a broader sample is needed. In addition, teachers in this study were selected based on snowball sampling and recommended by their principals. Another limitation involves the inquiry method the research team employed. Teaching practices and the process of integration is not easily researched through surveys and interviews. Teachers with thirty plus years of experience and teachers just out of college took similar surveys and because of that dichotomy the survey questions were purposefully vague to increase the likelihood that each would have experiences with that particular topic. The research team did not have experience with every technology tool or program that the participants did and had to use inferences to create under- 
standing among the responses. Finally, in this study teachers were not directly observed but practices and preparation to teach with technology were inferred from their descriptions of practice provided during the survey and interviews. Observations would provide a richer understanding of teacher experience with technology integration.

\section{Implications and Conclusions}

There are implications for practice, specifically related to the continued professional development of current teachers embedded within this study. Although there are now provisions for every new teacher in the United States to receive training in technology (U.S. Department of Education, 2010), it will be a long time before those teachers are the majority in school districts. Current teachers need professional development aimed at technology integration using both the content of their specialization and within the context of the classroom environment (Borko, Whitcomb, \& Liston, 2009; Ertmer, 2005). Even among teachers averaging 14 years' experience, technology integration in the classroom faces continuing barriers such as lack of continuing training. However, the majority of the teachers in this study $(n=1012)$ were able to describe complex technology integration practices suggesting that no matter the barriers teachers find a way to enact technology rich content where they can. The participants in this study view their experiences as informing their attitudes and beliefs on technology integration. Given that participants are working in schools across more than 200 corporations, there is a variety of processes described for the typical day using technology in the classroom. However, relatively consistent across all participants is the idea that simple exposure to technology would not facilitate 21 st century learning skills. Students and teachers need to interact with technology in order to make it worthwhile in the subject

specific activities. This finding is similar to what Perkins (2010) argues where learning is contextbased and focused on the individual.

The results of this study suggest that we should be exploiting the same technology tools for professional development that teachers use a daily basis. Authentic and current professional development for teachers should use blended learning, collaborative learning, and engage in the challenges of the current context (Gilchrist, Carpenter, Bowles, \& Gray-Bottle, 2012). Many teachers are still struggling to achieve meaningful technology integration within their classrooms (Ertmer, et al, 2012; National Education Association - American Federation of Teachers, 2008) while recent emphasis in 21 st century skills have pushed technology to the forefront of the classroom and learner experience.

\section{References}

Arrowood, D., Davis, R. A., Semingson, P., \& Maldonado, M. (2010, March). Supporting preservice teachers as they use technology to teach children. In Society for Information Technology \& Teacher Education International Conference (Vol. 2010, 1, 2138-2142).

Andrew, L. (2007). Comparison of teacher educators' instructional methods with the constructivist ideal. The Teacher Educator, 42(3), 157-184.

Arnone, M. P., Small, R. V., Chauncey, S. A., \& McKenna, H. P. (2011). Curiosity, interest and engagement in technology-pervasive learning environments: A new research agenda. Educational Technology Research and Development, 59(2), 181-198.

Becker, H. J. (1994). How exemplary computer-using teachers differ from other teachers: Implications for realizing the potential of computers in schools. Journal of Research on Computing in Education, 26, 291-321.

Becker, H. J. (2000). Findings from the teaching, learning, and computing survey: Is Larry Cuban right? Educational Policy Analysis Archives, 8, 51. Retrieved February 6, 2014, from http://epa.asu.edu/epaa/v8n51 
Bellanca, J., \& Brandt, R. (Eds.). (2010). 21st century skills: Rethinking how students learn. Bloomington, IN: Solution Tree Press.

Birch, T. (2008). Difficulties with Web 2.0: Some schools are not ready for interactive content. Retrieved March 3, 2015 from http://teachingtechnology.suite101.com/article.cfm/difficulties_with_web_20

Borko, H., Whitcomb, J., \& Liston, D. (2009). Wicked problems and other thoughts on issues of technology and teacher learning. Journal of Teacher Education, 60(1), 3-7.

Britten, J. (2012). Addressing and assessing 21st century skills in teacher education. Society for Information Technology \& Teacher Education International Conference, 1, 2714-2723.

CDW-G. (2006, June 26). Teachers Talk Tech reveals technology access and professional development are driving improved teacher and student performance. Retrieved March 14, 2015 from http://newsroom.cdwg.com/news-releases/news-release-06-26-06.html

Dede, C. (2010). Comparing frameworks for 21 st century skills. In J. Bellanca \& R. Brandt (Eds.), 21st century skills: Rethinking how students learn (51-76). Bloomington, IN: Solution Tree Press.

Dexter, S., \& Anderson, R. E. (2002). USA: A model of implementation effectiveness. Retrieved March 23, 2015, from http://citeseerx.ist.psu.edu/viewdoc/download?doi=10.1.1.455.6532\&rep=rep1\&type=pdf

Dwyer, D. C. (1991). Changes in teachers' beliefs and practices in technology-rich classrooms. Educational Leadership, 48(8), 45-52.

Ertmer, P. (2005). Teacher pedagogical beliefs: The final frontier in our quest for technology integration? Educational Technology Research and Development, 53(4), 25-39.

Ertmer, P. A., Ottenbreit-Leftwich, A. T., Sadik, O., Sendurur, E., \& Sendurur, P. (2012). Teacher beliefs and technology integration practices: A critical relationship. Computers \& Education, 59(2), 423-435.

Fisher, C., Dwyer, D. C., \& Yocam, K. (1996). Education \& technology: Reflections on computing in classrooms. San Francisco, CA: Jossey-Bass Publishers.

Gilchrist, P., Carpenter, E., Bowles, T., \& Gray-Battle, A. (2012). Investigating frequency and type of middle and high school teacher communication in a blended learning physics professional development program. Society for Information Technology \& Teacher Education International Conference, 1, 204209.

Giles, R. M., \& Shaw, E. L. (2011). SMART Boards rock. Science and Children, 49(4), 36-37.

Gray, L., Thomas, N., \& Lewis, L. (2010). Teachers' use of educational technology in U.S. public schools: 2009 (NCES 2010-040). Washington, DC: National Center for Education Statistics.

Hadley, M., \& Sheingold, K. (1993). Commonalties and distinctive patterns in teachers' integration of computers. American Journal of Education, 101, 261-315.

Hermans, R., Tondeur, J., van Braak, J., \& Valcke, M. (2008). The impact of primary school teachers' educational beliefs on the classroom use of computers. Computers \&Education, 51, 1499-1509.

Hew, K. F., \& Brush, T. (2007). Integrating technology into K-12 teaching and learning: Current knowledge gaps and recommendations for future research. Educational Technology Research and Development, 55, 223-252.

Hudson, S., Kadan, S., Lavin, K., \& Vasquez, T. (2010). Improving basic math skills using technology (Masters thesis). Retrieved from ERIC. (ED512698).

International Society for Technology in Education. (2008). National educational technology standards for teachers (2nd ed.). Eugene, OR: ISTE.

Jenkins, H., Purushotma, M. W., Clinton, K., \& Robison, A. J. (2009). Confronting the challenges of participatory culture: Media education for the 21st century. Cambridge, MA: MIT Press. 
Johnson, B. \& Christensen, L. (2008). Educational research: Quantitative, qualitative, and mixed approaches (3rd ed.). Thousand Oaks, CA: Sage Publications, Inc.

Koehler, M., \& P. Mishra (2009). What is technological pedagogical content knowledge? Contemporary Issues in Technology and Teacher Education, 9(1), 60-70.

Lau, K., \& Albion, P. (2010). Hong Kong home economics teachers' adoption of ICT for learning and teaching. Paper presented at Australian Computers in Education Conference: Melbourne, Australia. Retrieved March 15, 2015 from http://eprints.usq.edu.au/7354/2/Lau_Albion_ACEC_2010_PV.pdf

National Council for Accreditation of Teacher Education. (2011). Duncan praises NCATE and its Blue Ribbon Panel at release of administration's plan for educator preparation reform and improvement (NCATE News and Press Releases). Washington, DC: Author. Retrieved March 23, 2015 from www.NCATE.org

National Center for Education Statistics. (2006). Internet access in U.S. public schools and classrooms: 1994-2005 [Data file]. Retrieved March 1, 2015 from http://nces.ed.gov/pubs2007/2007020.pdf

National Education Association. (2008). Technology in schools: The ongoing challenge of access, adequacy, and equity (NEA Policy Brief \# 19). Washington DC: NEA Policy and Practice Department.

National Education Association - American Federation of Teachers (NEA - AFT). (2008). Access, adequacy, and equity in education technology. Results of a survey of America's teachers and support professionals on technology in public schools and classrooms. Retrieved from http://www.nea.org/assets/docs/PB19 Technology08.pdf

Patton, M. Q. (2002). Qualitative research and evaluation methods. Thousand Oaks, CA: Sage Publications.

Perkins, J. (2010). Personalising teacher professional development: Strategies enabling effective learning for educators of $21^{\text {st }}$ century students. Quick, 113, 15-19.

Phua, P. L., Wong, S. L., \& Abu, R. (2012). Factors influencing the behavioural intention to use the Internet as a teaching-learning tool in home economics. Procedia-Social and Behavioral Sciences, 59, 180187.

Pierson, M. (2001). Technology integration practice as a function of pedagogical expertise. Journal of Research on Computing in Education, 33(4), 413-430.

Project Tomorrow. (2011). The new 3 E's of education: Enabled, engaged, empowered-how today's educators are advancing a new vision for teaching and learning. Speak Up 2010 National Findings. Retrieved from http://www.tomorrow.org/speakup/speakup reports.html

Schrum, L., \& Levin, B. B. (2009). Leading 21st-century schools: Harnessing technology for engagement and achievement. Corwin Press.

Silva, E. (2009). Measuring skills for 21st-century learning. Phi Delta Kappan, 90(9), 630-634.

Stobaugh, R. R., \& Tassell, J. L. (2011). Analyzing the degree of technology use occurring in pre-service teacher education. Educational Assessment, Evaluation and Accountability, 23(2), 143-157.

Trilling, B., \& Fadel, C. (2009). 21st century skills: Learning for life in our times. San Francisco, CA: Jossey-Bass.

U. S. Department of Education. (2010). Transforming American education: Learning powered by technology. Retrieved from http://www.ed.gov/technology/netp-2010

Vannatta, R., \& Banister, S. (2009, March). Validating a measure of teacher technology integration. In Society for Information Technology \& Teacher Education International Conference (Vol. 2009, No. 1, pp. 1134-1140).

Wells, J., \& Lewis, L. (2006). Internet access in U.S. public schools and classrooms: 1994-2005. Retrieved from http://nces.ed.gov/pubs2007/2007020.pdf 
Zhao, Y., Pugh, K., Sheldon, S., \& Byers, J. L. (2002). Conditions for classroom technology innovation. Teachers College Record, 104(3), 482-515.

\section{Biographies}

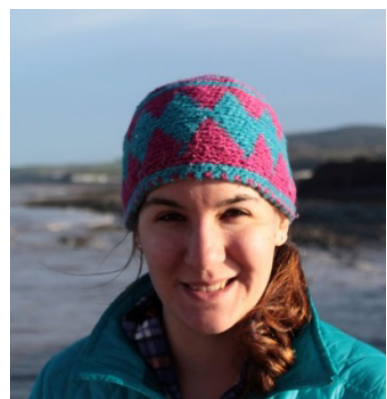

Dr. Dana Ruggiero is a Senior Lecturer of Learning Technology for the School of Education at Bath Spa University in Bath, United Kingdom. She received her doctorate in Learning, Design, and Technology at Purdue University in 2013. Her research interests include persuasive games, child computer interaction, and assessment.

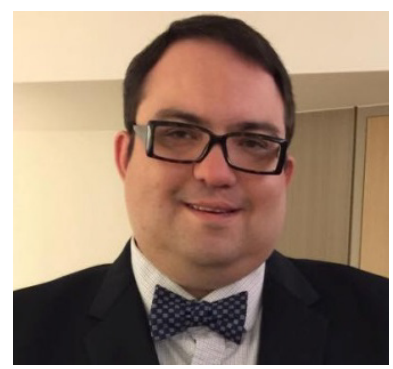

Dr. Christopher J. Mong is an Assistant Professor and Program Coordinator for the Learning Systems Technology Education master's program at the University of Arkansas at Little Rock. He received his doctorate in Learning, Design, and Technology at Purdue University in 2013. His research interests include problem-based learning, educational gaming and badging, teacher education, and academic transformation. 